\title{
Ethnobotany and Floral Characterization of Plants Used in Three Major Ethnic Groups in Cameroon to Treat Sinusitis
}

Ngouondjou Foze Teclaire $^{1 *}$, Mvogo Ottou Patrice Brice ${ }^{1}$, ETAME LOE Gisèle Marguerite ${ }^{2}$, Ngotta Biyong Jacques Bruno $^{1}$, Ndengue Jean De Matha ${ }^{4}$, Tamo Armel $^{4}$, Wansi Jean Duplex ${ }^{4}$, Priso Richard Jules ${ }^{1}$, Dibong Siegfried Didier ${ }^{1,2}$

${ }^{1}$ Department of Plant Science, Faculty of Sciences, B.P. 24157 Douala, Cameroon

${ }^{2}$ Department of Pharmaceutical Science, Faculty of Medicine and Pharmaceutical Sciences, University of Douala, B.P. 2701 Douala, Cameroon

${ }^{3}$ Department of Animal Science, Faculty of Sciences, University of Douala, B.P. 24157 Douala, Cameroon

${ }^{4}$ Department of Chemistry, Faculty of Sciences, University of Douala, B.P. 24157 Douala, Cameroon

DOI: $10.36348 /$ sjmps.2019.v05i12.009 $\quad$ | Received: 01.12.2019| Accepted: 08.12.2019| Published: 22.12 .2019

*Corresponding author: Ngouondjou Foze Teclaire

Email: nf_teclaire@yahoo.fr

\section{Abstract}

Very few ethnic groups in Cameroon have been subjected to ethnobotanical surveys and data on plants having medicinal properties against sinusitis which are very scarce. The current study is about exploring the Cameroonian flora in order to promote traditional medicine in the treatment of this affection. Ethnobotanical surveys were conducted among traditional healers and herbalists from villages and local markets in the Centre, Littoral, East and West provinces in order to identify the plants used by these four major cultural groups in Cameroon to treat sinusitis. After recipe characterization, the plant specimens were harvested and identified. Their floristic characterization and finally determining the composition of their bioactive metabolites were done. A total of 78 recipes involving 52 medicinal plant species were identified for sinusitis treatment; these recipes were prepared using plant combinations. These plants belong to 29 families, the most represented belong to the Fabaceae ( 7 species), Rutaceae ( 5 species) and Rubiaceae (4 species) families. $73.00 \%$ are woody plants from which the bark (56.00\%) is mainly collected. Fruits of Massullaria acuminata (29 occurrences), bark of Piptadeniastrum africanum (17), Erythrophleum suaveolens (9), Mammea africana (9), Cylicodiscus gabunensis (6) and leaves of Nicotiana tabaccum (5 occurrences) are the most commonly used organs to prepare the recipes which are mainly administered by nasal instillation $(60.77 \%)$. The bark of Antrocaryon klaineanum (6 occurrences), the stems of Costus afer (6) and the fruits of Citrus lemon (5 occurrences) are used as plant combinations. These plants are forest species $(62.00 \%)$ with regional distribution $(40.00 \%)$ whose diaspores are spread by zoochory $(97.00 \%)$. They contain many bioactive compounds, in particular phenolic compounds responsible for their pharmacological activities and thus justifies their use in the traditional treatment of sinusitis.

Keywords: Cameroonian cultural groups, ethnobotanical surveys, medicinal species, sinusitis, traditional medicine.

Copyright @ 2019: This is an open-access article distributed under the terms of the Creative Commons Attribution license which permits unrestricted use, distribution, and reproduction in any medium for non-commercial use (NonCommercial, or CC-BY-NC) provided the original author and source are credited.

\section{INTRODUCTION}

The number of people with respiratory infections worldwide is steadily increasing [1]. According to WHO, 235 million people are asthmatic, 64 million have chronic obstructive pulmonary disease (COPD), 8.7 million people contract tuberculosis, while millions more suffer from allergic rhinitis, sinusitis and other chronic respiratory diseases that are often not diagnosed [2].

Sinusitis is any inflammatory or infectious reaction localized in the cavities annexed to the nasal fossae. In other words, sinusitis is an inflammation of the naso-sinus mucosa that can be, in most cases, of viral, bacterial or fungal origin [3, 4]. According to its evolution, there are: acute sinusitis, whose evolution of symptoms does not exceed 4 weeks; sub-acute sinusitis, which lasts between 4 and 12 weeks and chronic sinusitis, evolving for more than 12 weeks [3]. This condition can bring into account the functional and vital prognosis, with heavy scars (visual, neurological and aesthetic) and thus have considerable socio-economic impact.

Sinusitis is a recursive condition that affects quality of life, has significant impacts on health care expenditures and has economic consequences via absenteeism and loss of productivity [4]. In Canada, 2.89 million prescriptions were issued in 2006 for 
the treatment of acute rhinosinusitis, 26 million people in the United States in 2007 were prone to this condition, which also caused 12.9 million office consultations [4, 5]. In Africa, although there are no precise data on the prevalence of sinusitis, its damage is increasing with pollution, increasing impoverishment and resistance of infectious agents to conventional drugs.

After having been long under the influence of synthetic drugs and their side effects, man is gradually rediscovering the benefits of nature through phytotherapy, with proven effectiveness over and the undeniable benefits in the health field [6]. The resistance developed by infectious agents to conventional drugs, their high cost and proven toxicity led national and international policies in the late 1970s to subscribe to the idea of exploiting the indigenous knowledge and existing local capacities of populations in developing countries to solve health problems [7]. The developed countries are not to be outdone because the use of indigenous know-how is experiencing a renewed interest, mainly for the production of new pharmaceutical drugs $[8,9]$.

Most tropical countries, both in rural and urban areas, have poorly developed or even nonexistent health facilities. Despite the advent of generic drugs, many treatments remain financially inaccessible to these economically deprived populations. As a result, millions of people have turned towards the use of traditional medicine as first line therapy for their primary health care. This is due to the fact that it remains the most affordable and therefore, seems to be the most effective for their primary health care. Many studies carried out in Africa at large and Cameroon in particular, have identified and catalogued many medicinal plants used for the treatment of respiratory diseases [1, 10-15]. However, despite the efforts made and despite the richness of the Cameroonian flora in medicinal plant species, a large number of villages have not yet been subjected to surveys in ethnobotanical studies and more specifically on studies involving medicinal plant species that can treat sinusitis.

The current study therefore aims to explore the Cameroonian flora of three major cultural groups with a view to enhance the traditional pharmacopoeia in the treatment of sinusitis. Specifically, (1) inventory the medicinal plants used by the peoples of the western plateau, the coastal-tropical rainforest as well as those of the southern tropical forests to treat sinusitis; (2) characterize these plants; (3) determine the pharmacological and phytochemical composition of some of these plants that would elucidate their biological effect.

\section{MATERIAL AND METHODS Study Site}

Cameroon is a country of Central Africa located at the bottom of the Gulf of Guinea, between longitudes $9^{\circ}$ and $16^{\circ}$ East and latitudes $2^{\circ}$ and $13^{\circ}$ Nord. The territory is roughly triangular with a base that stretches from west to east over $800 \mathrm{Km}$ and a height that stretches south to Lake Chad for nearly $1,200 \mathrm{Km}$ and covers a total surface area of 475,650 $\mathrm{Km}^{2}$. It has a maritime boundary of $420 \mathrm{Km}$ along the Atlantic Ocean to the southwest. To the south it borders Equatorial Guinea, Gabon, and Congo; to the west Nigeria; to the east by the Central African Republic; to the north-east by Chad and to the top of the triangle to the north, it is capped by Lake Chad. Cameroon is often referred to as "Africa in miniature" due to the broad diversity in ecology, culture, and languages (Figure-1).

The climate and terrain are variable across the country and contribute to the geographical diversity with the southern forest (Centre, East, Littoral, South and South-West regions) located in the maritime and equatorial zones [16]. This area is characterized by dense vegetation, a vast hydrographic network and a hot and humid climate with abundant rainfall. This area is conducive for the cultivation of cocoa, palm oil, banana, rubber and tobacco. It is home to the two largest cities of the country: Douala (first city, main port and economic capital with its commercial and industrial activities) and Yaounde (second city and political capital). There are also major urban centres such as Edea, with its heavy industry and hydroelectric power; Limbe, headquarters of the oil industry and Kribi, the terminal of the Chad-Cameroon pipeline. The western highlands (West and North-Western Regions), with an average altitude of more than $1,100 \mathrm{~m}$, form a region rich in volcanic soils favorable for agriculture (coffee, market gardening, etc.). The vegetation is less dense than in the southern forest and the cool climate prevails in all kinds of activities. The main cities are Bafoussam, Bamenda and the university city of Dschang. The northern Sudanese Sahel (Adamaoua, North and Far North Regions) is an area of savannah and steppes. Apart from the Adamaoua plateau, where the climate is more temperate, the rest of the region is characterized by a hot and dry tropical climate with increasingly limited rainfall as we approach Lake Chad. The region is favourable for cattle breeding and the cultivation of cotton, onion, millet, potato, white yam and peanuts. 


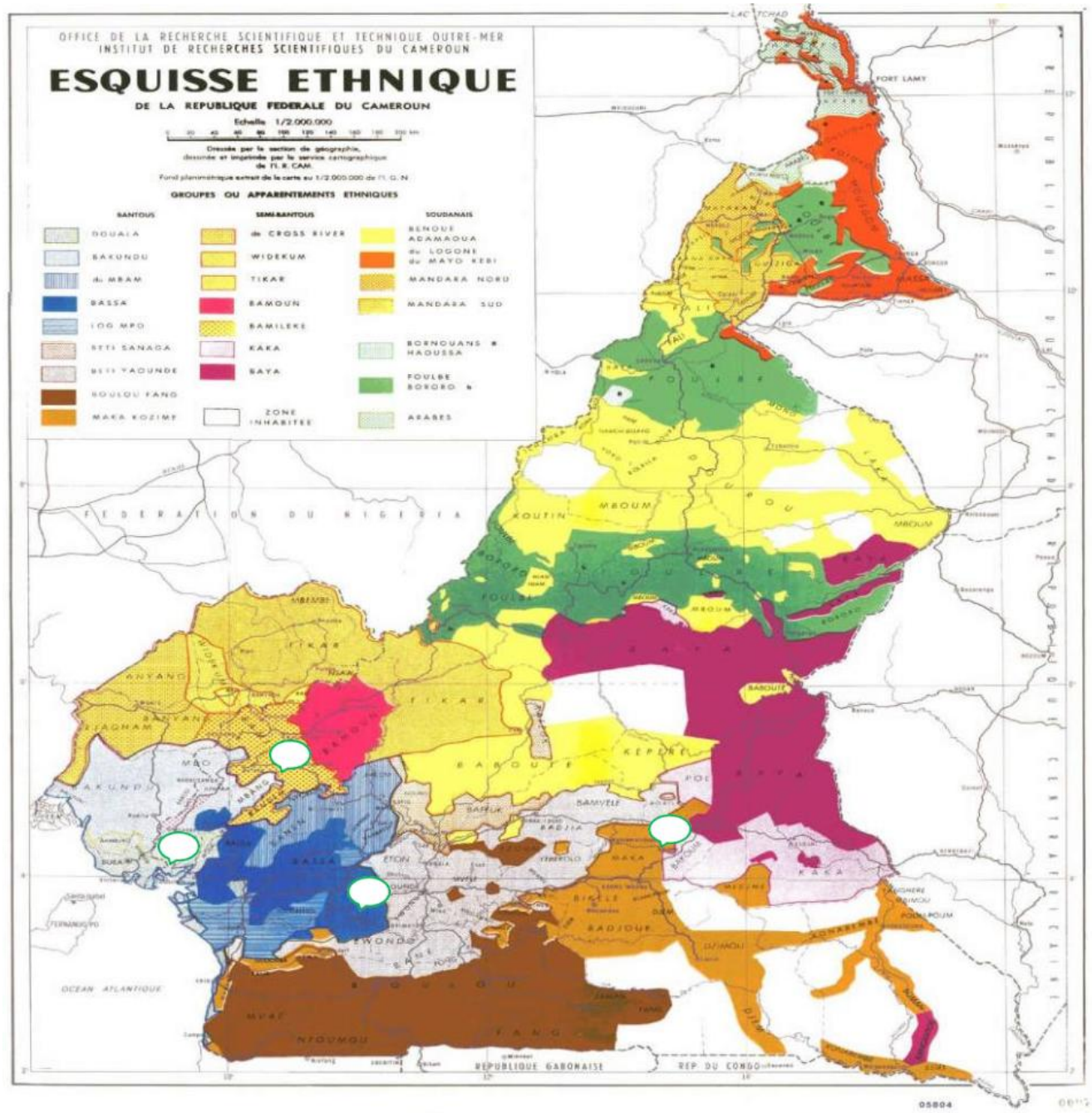

Fig. 1: Map representing the ethnic groups of Cameroon and showing the main study areas

Source: Office de la Recherche Scientifique et Technique Outre-mer, Institut de Recherche Scientifique du Cameroun.

Cameroon has more than 200 different ethnic groups that form five major cultural regions, namely: the peoples of the western plateaus, including the Bamileke, Bamoun and other groups in the northwest, the peoples of the coastal tropical forests, including the Bassa, Douala and other entities in the southwest, the peoples of the southern tropical forests including the Beti or Pahouins, Boulou, Ewondo and Fang (subgroups of the Beti-Pahouin) and the Baka pygmies, the peoples of the semi-arid northern regions (the Sahel) and the central lands including the Fulani and finally, the animist peoples (the Kirdi) in the northern desert and the central lands which in general have escaped
Islamization [17, 18]. These ethnic groups are mixed in the big cities and live together without any problems. Each group preserves its cultural values, dialect and attachment to their villages of origin where family and friends meet regularly for meetings, celebrations or funerals. This diversity contributes to the country's cultural richness and stability. The choice of the villages was made taking into account ethnic groupings and the availability of indigenous natives to contribute to this study; the choice of markets was determined by the importance of marketing NTFPs in the markets of the regions visited (Figure-2). 


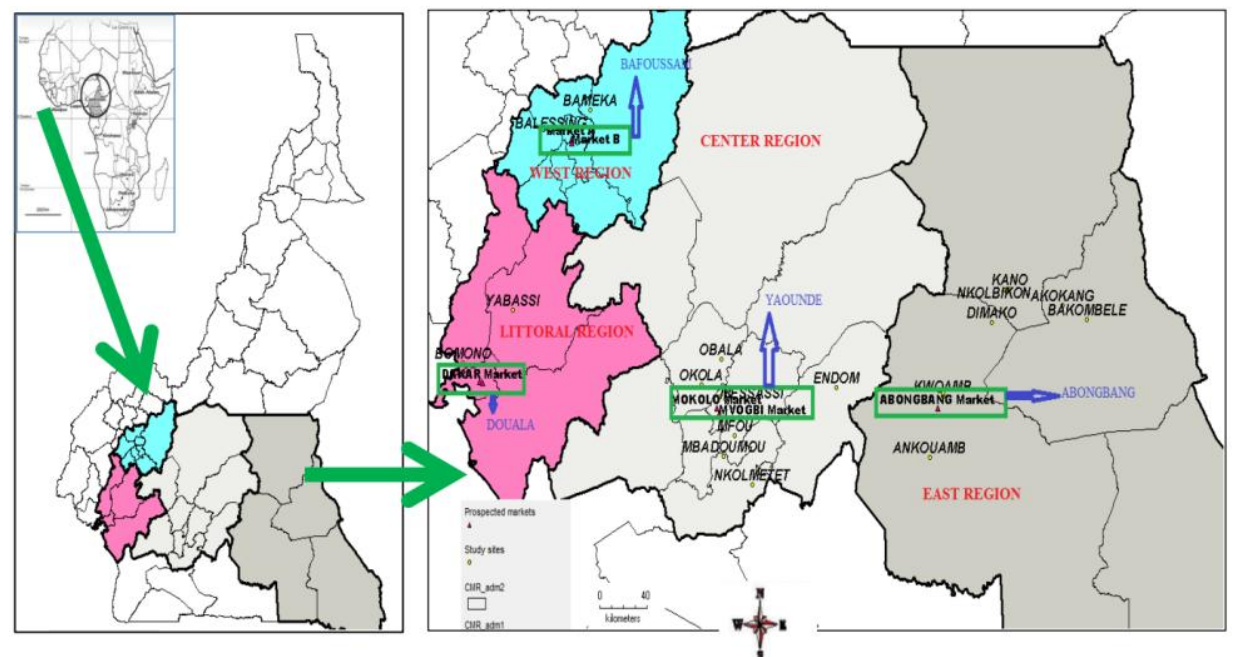

Fig-2: Map showing the sites (villages and markets) concerned by ethnobotanical surveys

\section{Ethnobotanical Survey}

Series of ethnobotanical surveys were conducted in different villages and markets of four regions (Centre, Littoral, East and West) in Cameroon belonging to three major cultural groups including the peoples of the southern tropical forests, the peoples of the coastal tropical forests as well as the peoples of the western plateaus. These surveys were semi-structural surveys designed to assess healers' knowledge of respiratory disease conditions and more precisely to identify the different recipes used by them to treat sinusitis. They were conducted between March and September 2016 on the basis of a survey sheet, the main lines of which concerned information on the plants used to prepare recipes administered for respiratory tract diseases in general and those administered for sinusitis in particular, the method of preparing the said recipes, their methods of administration and the other diseases treated by these plants. The population approach was based on dialogue in French and/or local languages (Ewondo, Eton, Baka, Maka, Douala, Bassa, Bamoun, Bafoussam and Bameka). Access and interviews in the villages were facilitated by an indigenous guide from each village who translated the local language into French. Twenty-seven (27) villages including 14 in the East, 9 in the Centre, 2 in the Littoral, 2 in the West and 7 markets including 2 in the Centre, 2 in the Littoral, 2 in the West and 1 in the East were visited with a total of 434 respondents including 192 men and 242 women, all with an average age of 49 years and an average experience of 18 years in traditional therapy. These respondents were traditional practitioners, nurses, herbalists selling medicinal plants in markets, healers with ancestral knowledge, farmers as well as retired civil servants. All were able to list and describe the symptoms of sinusitis while naming it in local languages, but not all were able to provide treatment. Those able to provide treatment first mentioned the different respiratory diseases they knew, specified those they were able to treat, and after giving the signs and symptoms of sinusitis, provided all the information on the recipes used in its treatment including the description and/or harvesting of the various plants used in each of the recipes.

\section{Specimens' Collection and Identification}

Sample collection in the villages was done in situ thanks to the respondents' availability and willingness to enter the bushes to harvest the different plant organs. Symbolic gifts were presented to the respondents which covered the rights of acquisition of knowledge and as machete right for the entry into the bushes for the harvest of the plant organs. In markets, however, specimens were obtained by simply purchasing the plant organs used in the recipes indicated. These samples were photographed and then conserved in a control herbarium using techniques [19]. Identification was done by simply comparing the vernacular and/or commercial names obtained from the respondents, available literature of samples in the herbarium, websites (PROTAU4.ORG) and reference material available in the Laboratory of Biology and Physiology of Plant Sciences at the University of Douala. Identification was finally approved by specialised botanists of the Cameroon National Herbarium.

\section{Characterization of the identified PFNLs florets}

The PFNLs florets collected were characterized by: the types of phyto-geographic distribution, the morphological types, the types of biotopes, and the types and modes of diaspores dissemination [20-24].

\section{Characterization of the phytochemical profile of species used in recipes}

The phytochemical and pharmacological data of the species retained for their high degree of solicitation in the recipes for treating sinusitis were sought in pharmacological journals based on previous works of said species. This research focused specifically on the predominant bioactive metabolites in 
each plant and the relatively close relationship between these metabolites and the pharmacological importance of the plant species [25].

\section{Data Entry and Analysis}

The data analysis began by entering the different recipes and their characteristics per site and per informant in an Excel spreadsheet Version 2013. This was followed by the encoding of the informants and finally the statistical processing of the various data. Taking into account the large number of informants per site visited, it was simpler and more appropriate to group them by village and market visited and not per respondent as described in the [25]. Thus, all information obtained from respondents in a site was considered to be provided by a single informant. A dendrogram based on the similarities of plants used to treat respiratory tract diseases per region and per site (village and/or market) was established from the Jaccard similarity coefficient using the XIStat software. The calculation of this coefficient is based on the simple presence or absence of a species in a recipe cited by all informants at the same site. It quantifies the degree of species association and the level of similarity between recipes by taking into account the plants that are used [25].

Quantitative analysis of ethnobotanic data is one of the means to identify plants with pharmacological importance. A quantitative data analysis has been reported to increase the probability of finding promising plants [26]. The relative importance of a plant cited by respondents for sinusitis is established based on the number of "events" i.e the number of citations occurring in different recipes. Indeed, according to Betti et al., [27], the higher the number of citations of a plant is for a given disease, the more the plant is confirmed for use in traditional medicine to treat a disease condition.

\section{RESULTS}

\section{Characterization of recipes}

Respondents from the various survey sites cited 145 recipes to treat coughs, which is the principal and the most well-known respiratory affection handled by traditional healers. 66 plants were mentioned for the treatment of this disease via traditional medicine among which Garcinia Kola Heckel., Trichoscypha acuminata Engl., Zingiber officinale Rosc., Pycnanthus angolensis (Welw). Excell and Hylodendron gabunense Taubert are the most cited for the traditional treatment of bronchitis, an ailment requiring much more animal parts and other natural non-plant elements for its treatment. In total 76 recipes were cited and 9 plants were frequently solicited among which Spathodea campanulata $\mathrm{P}$. Beauv. and Ocimum gratissimum Linn.

The traditional healers were also able to solve problems related to asthma and tuberculosis. With regard to asthma, 62 recipes were recorded. These recipes involve 33 species of medicinal plants with Allium sativum Linn. and Eucalyptus globulus Labill being the most frequently used. On the other hand, to treat tuberculosis, 54 recipes involving 32 species of medicinal plants were cited. According to the traditional healers interviewed, tuberculosis is the most difficult disease to treat among respiratory diseases. Guibourtia demeusei Harms, Cylicodiscus gabunensis Harms, Allium sativum Linn, and Entandrophragma candollei Harms are the most used plants for the treatment of this disease condition.

To treat sinusitis itself, respondents from the different surveyed sites mentioned 78 recipes. It is the disease for which the plants used were unanimously accepted by more than $60 \%$ of respondents. The recipes for this disease involve 52 species of medicinal plants, some of which are used only as mono-therapy. These are Nicotiana tabaccum Linn, Allium sativum Linn., Enantia chlorantha Oliv., Boswellia sacra Flueck, Solanum aculiastrum (C. H. Wright) Bitter, Capaifera religiosa J. Leonard, Carica papaya Linn., Ceiba pentandra (Linn.) Gaertn, Entandrophragma cylindricum Sprague, Guibourtia demeusei, Oxalis corniculata Linn., Solanum melongena Linn. and Zanthoxylum heitzii (Aubr. \& Pell.) Waterman. Others are solicited both as mono therapy and as plants combinations. These include; Massullaria acuminata (G. Don) Bullock ex Hoyle, Piptadeniastrum africanum (Hook. f.) Brenan, Mammea africana Sabine, Cylicodiscus gabunensis Harms, Erythrophleum suaveolens (Guill. \& Perr.) Brenan, Mitragyna stipulosa (DC.) Kuntze, Musanga cecropioides R. Br. and Spathodea campanulata P. Beauv. Thirty other species were solicited in the recipes administered in the treatment of sinusitis only as plant combinations. Different plant organs are equally used to prepare recipes for the treatment of sinusitis. These include plant barks, fruits, leaves, stems, rhizomes and roots. Of these organs, the barks of the plants are mostly used $(56 \%)$ in the recipe's preparations (Figure-3). 


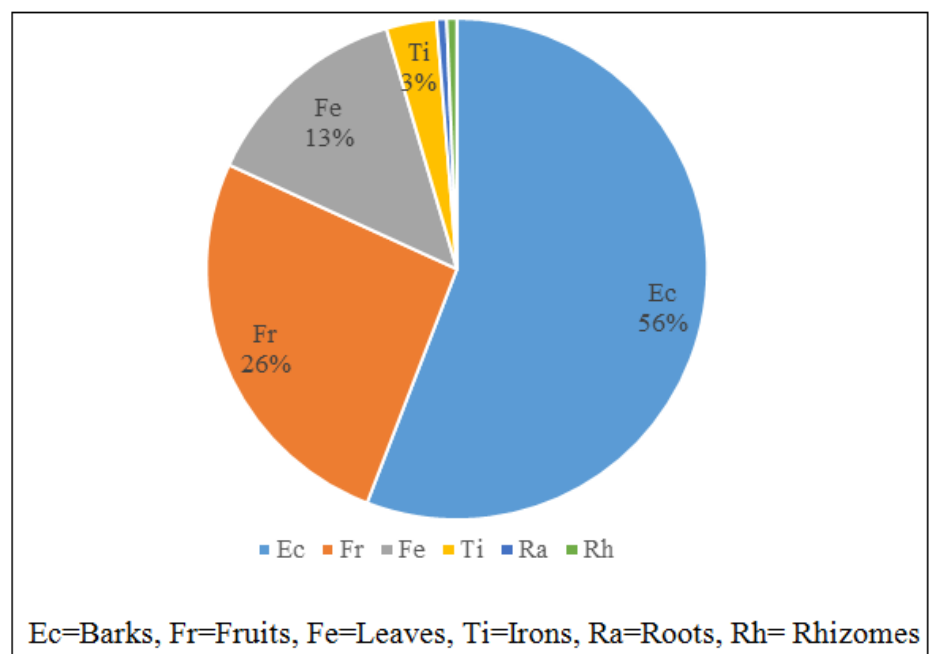

Fig-3: Vegetative organs of plants identified for the treatment of sinusitis

Several modes are used by traditional healers to prepare recipes for the treatment of sinusitis. These include: (1) crushing the fresh fruit, adding a little juice and then bundled in the leaves of Musa sp. Linn., of Xanthosoma sagittaefolium (Linn.) Schott or Anchomanes difformis (Blume) Engl. then heated over low flame; (2) dunk the fresh or dry bark of the specimen with water for 30 to 45 minutes; (3) scrape the fresh bark of the specimen then macerate in a little water or juice of Costus afer ker Gawl. or Citrus lemon (Linn.) Burm F. fruits; (4) heat the leaves over low flame to soften it, then crush and collect the juice; (5) crush, bundle the crush in the leaves of Musa sp., Xanthosoma sagittaefolium or Anchomanes difformis; (6) spray the dry organs by grinding or crushing them and store the powder; (7) macerate the organs in a little water for 12 hours and finally (8) ferment the crushed organs in Citrus lemon or Citrus aurantifolia Linn. juice. These methods of preparation represent respectively $30.66 \% ; 22.66 \% ; 14.66 \% ; 9.33 \% ; 6.66 \%$; $6.66 \% ; 5.33 \%$ and $4 \%$.

Sinusitis recipes are available in liquid $(86.90 \%)$ and powder formulations $(13.10 \%)$. They are administered to patients via nasal route $(59.52 \%)$; oral route $(32.14 \%)$; rectal route $(7.14 \%)$ and by body bath (1.19\%) (Figure-4). Five (05) modes are used by traditional therapists to administer these recipes. These are: nasal instillation of 1 to 2 drops per nostril once a day $(60.77 \%)$; drinking 1 glass in the morning and 1 evening each day (28.57\%); purging once every 2 to 3 days $(7.14 \%)$; regular consumption of a few spoons of powder $(2.3 \%)$ and finally washing the head morning and evening (1.19\%). The use of Musa sp., Xanthosoma sagittaefolium, Anchomanes difformis and Cafea arabica Linn. leaves are in high demand to administer the recipes to patients via nasal instillation.

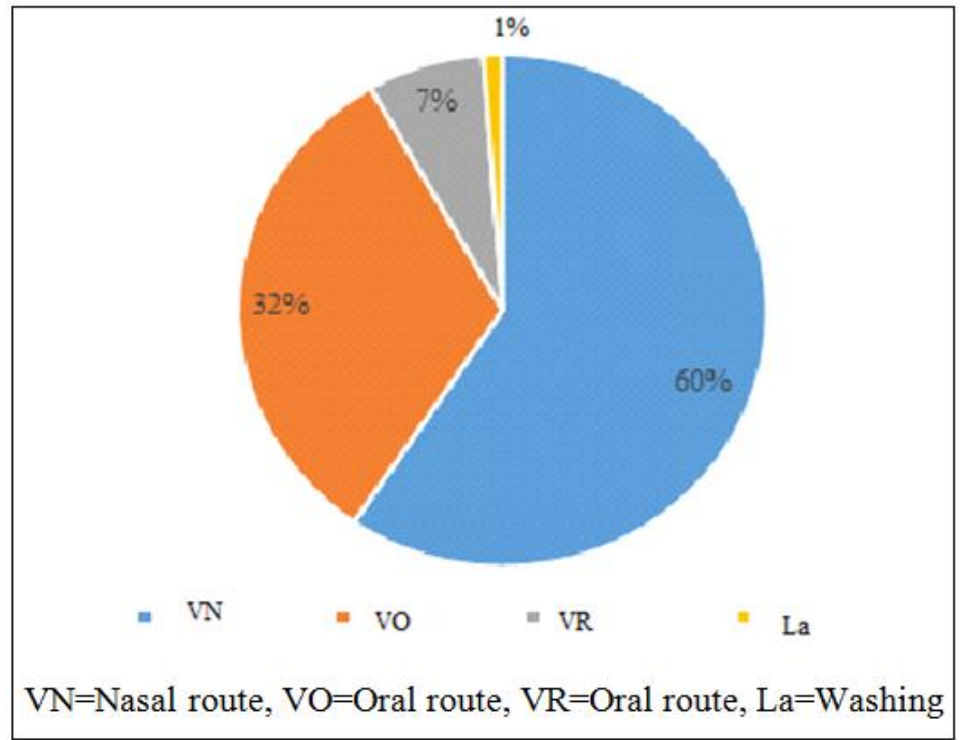

Fig-4: Administration routes of herbal recipes used to treat sinusitis 


\section{Similarities in therapists' knowledge of plant use}

In order to compare the knowledge of major cultural groups on the use of medicinal plants to treat respiratory tract disorders in general and sinusitis in particular, a similarity matrix obtained from the Jaccard similarity coefficient was generated. The Jaccard index focuses on the simultaneous presence of a plant in several communities or sites. Thus, the calculation of a similarity coefficient makes it possible to quantify the degree of association of two species, or the level of similarity between two sites taking into account their floristic composition. The intra-class variances made it possible to identify sites with strong similarities, sites with moderate similarities and finally sites with very low similarities. V1L (Village 1 of the Littoral) and M2L (Market 2 of the Littoral) have a very high intraclass variance (13.50) and therefore have very similar floristic compositions and therefore a strong similarity. The villages and markets M1L, V3C, M2C, V7C, V8C, $\mathrm{V} 8 \mathrm{C}, \mathrm{V} 4 \mathrm{C}$ and $\mathrm{V} 2 \mathrm{~L}$ have an average intra-class variance (8.80) and therefore their plant compositions are moderately identical and therefore these sites have average similarities (Figure-5).

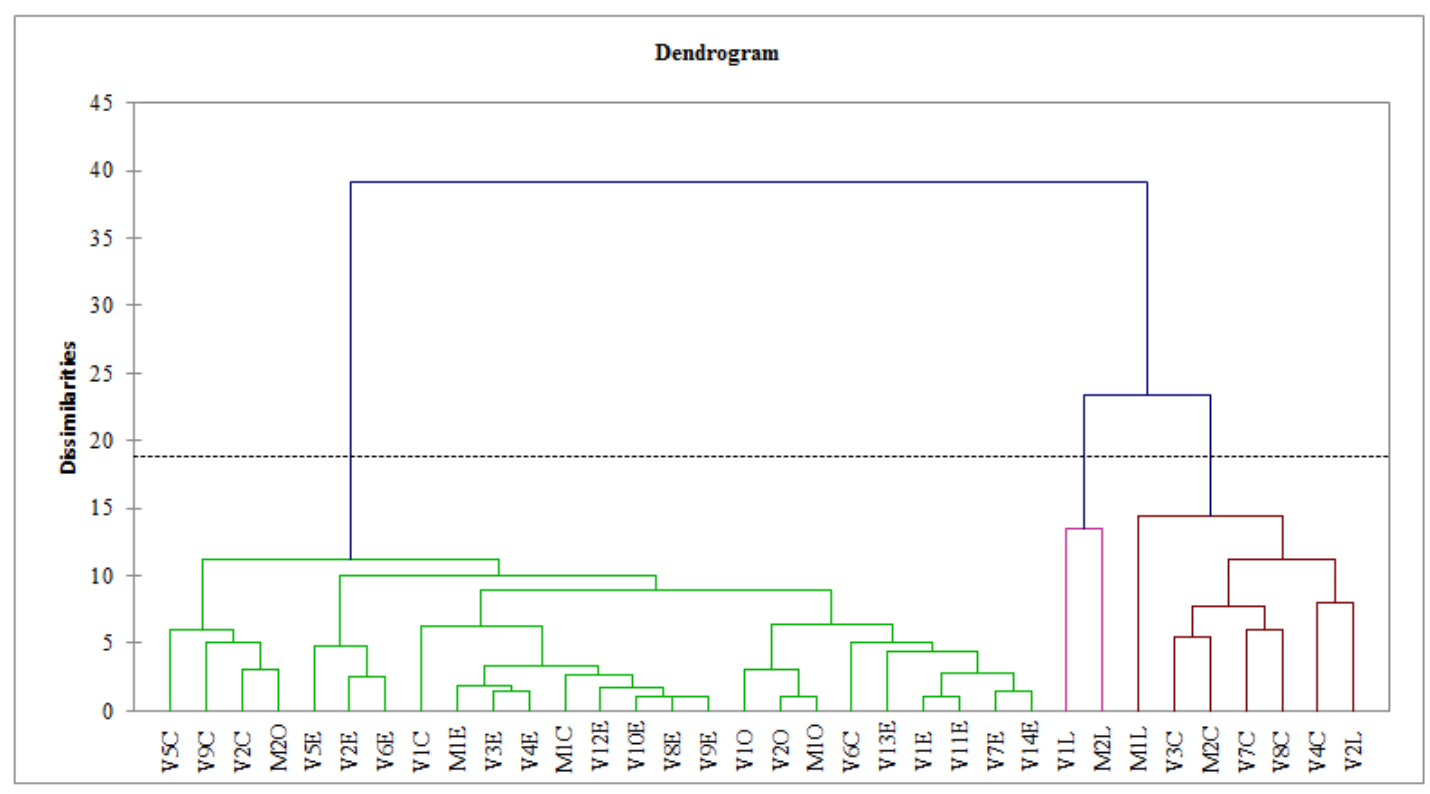

Fig-5: Dendrogram presenting the similarities of uses of plants against respiratory tract diseases, more precisely sinusitis, between markets and villages in Central, Littoral, Eastern and Western Cameroon

$\mathrm{V}=$ Village, $\mathrm{M}=$ Market, $\mathrm{C}=\mathrm{Centre}, \mathrm{L}=$ Littoral, $\mathrm{E}=$ East, $\mathrm{O}=$ West. V5C=5th Central Village where the ethnobotanical survey took place, $\mathrm{M} 1 \mathrm{E}=1$ st eastern market where the survey took place

\section{Description of the recipes of some plants of interest}

The plants of interest for the treatment of sinusitis were determined by the number of times they are used in recipes to treat sinusitis. A given plant species will thus be considered effective against this disease when it is cited at least twice for its treatment.

Massullaria acuminata (G. Don) Bullock ex Hoyle (Rubiaceae), Shimpanzé/Shouamm (Maka dialect), Oyebe (Beti dialect), Leehhh (Bamoun dialect), Ntii (Bamileke dialect): the fruits of this shrub are used 29 times in the recipes to treat sinusitis, 24 times as the main plant and 5 times as plant combination in other recipes. The preparation of the recipes consists in grating a green fruit of Massullaria acuminata, fresh organs preferably then, scraping the fresh inner part of the bark of Piptadeniastrum africanum, add a few drops of the previously washed pressed juice of Costus afer stem. With a dropper or using a traditional funnel based on a Musa sp. leaf, or Anchomanes difformis, introduce 1 to 2 drops of the preparation into each nostril once a day; preferably before sunrise or after sunset. Head bent backwards, eyes raised towards the sky for 2 to 3 minutes, avoid inhaling and avoid using the recipe more than twice a week. Store the recipe at ambient temperature but for not more than 2 weeks away from the sun.

Piptadeniastrum africanum (Hook.f.) Brenan (Mimosaceae), Atui (Beti dialect) is a forest tree whose bark is used 17 times in the recipes used to treat sinusitis; 13 times as the main plant and 4 times in associations with other plants. The preparation of the recipe consists of harvesting the Piptadeniastrum africanum bark, scraping the fresh inner part of this bark and then mix with the bark rasps of Mammea africana, Erythrophleum suaveolens and Massullaria acuminata fruits. Add a few drops of water to moisten and homogenize the mixture, and then allow at room temperature for about 30 to 60 minutes. Using a dropper, make a nasal instillation of 1 to 2 drops of the recipe in each nostril, keeping the head tilted backward 
for a few minutes. Avoid using the recipe more than three times a week, store it for not more than 2 weeks at room temperature and away from the sun.

Erythrophleum suaveolens (Guill. \& Pierr.) Bren. (Caesalpiniaceae), Elone (Beti dialect), Tali (Trade name) is a large forest tree whose bark is used in 9 recipes (7 times as main plant and 2 times as plant combinations). Specifically, the dry bark of Erythrophleum suaveolens is sprayed and the powder is used as a nasal dose morning and evening every day or once every 2 days depending on the severity of the disease. Erythrophleum suaveolens powder can be stored for several months when it is not in contact with the air.

Mammea africana Sabine (Clusiaceae), Aboadzoak (Beti dialect) is a forest tree whereby the barks are used in 9 recipes to solve problems related to sinusitis; that is 5 times as main plant and 4 times as associated plant in other recipes. Specifically, the fresh bark of Mammea africana is grated and the rasp is mixed with the bark rasps of Antrocaryon klaineanum Pierre, Cylicodiscus gabunensis Harms and Enantia chlorantha Oliv. To this mixture is added a few drops of water or Costus afer stem juice and then the mixture is left at ambient temperature for 6 to 12 hours. This recipe is administered by nasal instillation to patients daily for 3 to 4 weeks. The same organs are decocted for 45 to 60 minutes. This decoction is taken as a drink in a glass three times a day. The recipe can be kept for a maximum of 1 week in a dark place and the decoction must be reheated on the 3rd day before being consumed.

Nicotiana tabaccum Linn. (Solanaceae), Ntolok (Maka dialect), Taah (Beti dialect), Tobacco (Trade name) is a shrub whose fresh or dry leaves are used exclusively as the main plant in 5 recipes to treat sinusitis. Dry leaves of Nicotiana tabaccum are sprayed and the powder is kept away from the air for several months and used as a nasal plug on a regular basis. When fresh, these leaves are crushed and bundled in the leaves of Coffea arabica Linn. or Xanthosoma maffafa (Linn.) Schott in the form of a traditional funnel and then heated over low flame. This recipe is used every day morning and evening for a week via nasal instillation of 1 to 2 drops per nostril. It must be heated before use and its use is prohibited for more than one week.

Allium sativum Linn. (Liliaceae), Garlic (Trade name) is a common cultivated herb whose fruits are used in 3 recipes exclusively as the main plant. Fresh or dried, some Allium sativum fruits are crushed and mixed with a few drops of Citrus lemon (Linn.) Burm. fruit juice. The mixture is left to ferment for 1 hour and will be administered to patients by nasal instillation of 2 drops in each nostril twice a week. This recipe can be stored in a cool environment for up to 4 weeks.

Enantia chlorantha Oliv. (Annonaceae) Nfol (Beti dialect), Jen béah (Maka dialect), Yellow bark (Trade name) is a forest tree where the barks are used in 3 recipes only as the main plant. The bark of Enantia chlorantha is decocted with that of Cylicodiscus gabunensis, Antrocaryon klaineanum and Hylodendron gabunense Taubert for 30 to 45 minutes. This decoction is administered to the patient by oral, rectal and nasal routes. Indeed, the patient is given to drink in a glass 3 times a day, the purging is done every three days with the warm preparation and a few drops (2 to 3 ) are introduced into each nostril morning and evening. This recipe is kept at ambient temperature for a maximum of 2 weeks. The organs can both be used fresh and dried and can be conserved for several months.

Solanum aculiastrum (C. H. Wright) Bitter (Solanaceae), Jongo (Maka dialect), Wild eggplant (Trade name) is a shrub whose fruits are used in 2 recipes only as a main plant to treat sinusitis. Precisely, to the gratered fruits ( 2 to 3 fruits) is added a few drops of the juice of 1 fruit of Citrus lemon and the mixture is left for 1 to 2 hours. The juice from this homogenate is collected and administered to the patient via nasal route once a day for 2 weeks at a rate of 1 drop per nostril. This preparation can only be used for a maximum of 1 week.

Entandrophragma candollei (Dawe \& Sprague) Sprague (Meliaceae), Atom assieh (Beti dialect), Chié (Maka dialect), Koudjock/sapelli (Trade name) is a forest tree whose bark is used just once as the main plant and also just once as an associated plant in preparations to treat sinusitis. Precisely, these barks are decocted for 30 to 45 minutes with that of Guibourtia tesmannii (Harms) Leonard, Musanga cecropioides $\mathrm{R}$. Br. and Antrocaryon klaineanum. The decoction is administered 3 times a day as a drink, and once every forth night by instillation of 2 drops in each nostril for 1 to 2 weeks.

Spathodea campanulata P. Beauv. (Bignoniaceae), Evevone (Beti dialect), Tourouk (Bameka dialect), Tulip tree (Trade name): the bark of Spathodea campanulata is used in 2 recipes (as the main plant in one and as an associated plant in another) to treat sinusitis. Specifically, the bark of Spathodea campanulata is decocted with that of Ricinodendron heudelotii (Baill.) Pierre ex Heckel, Canarium schweinfurthii Engl. and Antrocaryon klaineanum. This decoction is taken as a drink 3 times a day, by means of purging every three days as well as via instillation 2 drops per nostril morning and evening. This recipe is kept at ambient temperature for a maximum of one week. 
Musanga cecropioides $\mathrm{R}$. Br. (Cecropiaceae), Asseng (Beti dialect), Shien (Maka dialect), Parasolier (Trade name) is used twice in recipes to treat sinusitis. Once in a decoction where the bark is used in combination with another bark, and once as the main plant where the roots of Musanga cecropioides are injured very early in the morning and the sap from these roots is collected after a while. This sap is mixed with the bark of Alstonia boonei De Wild. Using a dropper, two drops of this mixture are introduced into each nostril morning and evening for a week.

$\begin{array}{rrr}\text { Cylicodiscus } & \text { gabunensis } & \text { Harms } \\ \text { (Mimosaceae), Adoum } & \text { (Beti } & \text { dialect), }\end{array}$
Panseu/Deumpahhh (Bameka dialect), Loum (Douala/ Bassa dialect): the bark of Cylicodiscus gabunensis is used in 6 recipes (in 2 as main plant and in 4 as plant combinations) to treat sinusitis. Precisely, these barks are decocted with those of Antrocaryon klaineanum, Piptadeniastrum africanum and Anonidium mannii (Oliv.) Engl. \& Diels. This decoction is given to patients as a drink, a glass 3 times a day, purged once every three days and by nasal instillation of 2 drops per nostril morning and evening.

Mitragyna stipulosa (DC.) Kuntze (Rubiaceae) Elelouam (Beti dialect): the bark of this tree is used in a recipe as the main plant and in another as an associated plant. When used as a main plant, the dried bark of Mitragyna stipulosa is sprayed and the powder is mixed with the bark of Fagara macrophylla (Oliv.) Engl. and Erythrophleum suaveolens. This powder mixture is used via instillation in each nostril morning and evening every day or once every 2 days. This powder can be stored for several months when it is not in contact with the air.
Many other species are also plants of interest, although they are only used as associated plants in recipes to treat sinusitis. These are: Antrocaryon klaineanum Pierre (Anacardiaceae) called Angongui in Beti dialect whose bark is used in 6 recipes; Costus afer Ker Gawl. (Costaceae) called Mien in Beti dialect, Miandji in Maka dialect and commonly called twin cane and whose stem juice is used 6 times in recipes; Citrus lemon (Linn.) Burm. (Rutaceae) called Ofoumbe beti in Beti dialect and Lemon in commercial language whose fruit juice is used in 5 recipes; Musa sp. Linn. (Musaceae) commonly known as Banana/plantain and Anchomanes difformis (B1.) Engl. (Araceae) called Dindela bedimo in Douala dialect or wild macabo in commercial language whose leaves are used in 5 and 3 recipes respectively to make traditional funnels to heat recipes over a low heat and administer to patients by nasal instillation; Alstonia boonei De Wild. (Apocynaceae) called Ekouk in Beti dialect, Kougueu in Maka dialect and Emien in Bassa dialect, Guilbourtia tesmannii Harms (Caesalpiniaceae) called Essingang in Beti dialect, Hylodendron gabunense Taubert (Caesalpiniaceae) called Landeuh in Maka dialect whose bark is all requested in three recipes each; Nauclea diderrichii (De Wild.) Merril (Rubiaceae) commonly called Bilinga and Akoongo in Beti dialect and whose bark is used in 2 recipes to treat sinusitis.

\section{Floral characteristics of the species}

Of the 52 species of medicinal plants identified to treat sinusitis, 38 are ligneous and 14 are herbaceous. They are divided into 27 genera belonging to 29 families, the most represented being Fabaceae (7 species), followed by Rutaceae (5 species) and Rubiaceae (4 species). Among ligneous, mainly trees are cited (32 occurrences) with a frequency of $84.21 \%$ (Figure-6).

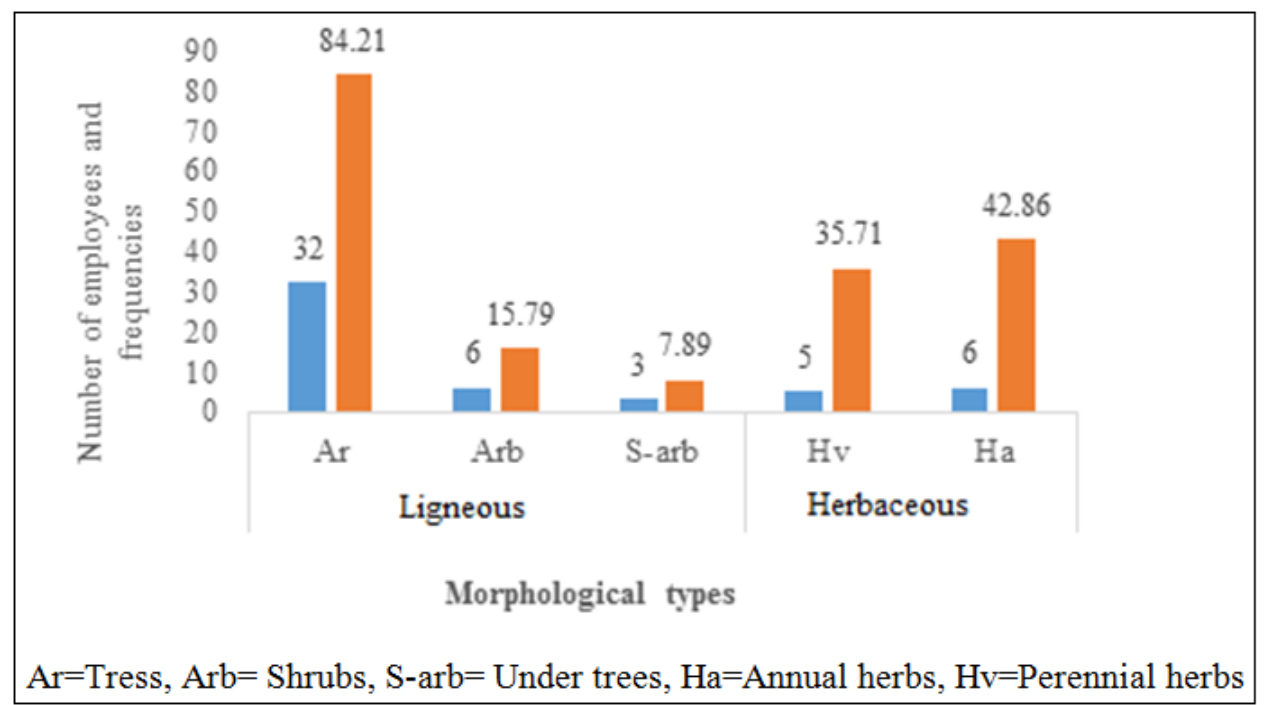

Fig-6: Histogram (\% in quotation) of morphological types

The proportions of the phytogeographic distribution of medicinal plant species identified in the treatment of sinusitis highlight the predominance of species with regional distribution (40\%). Of these 
regionally distributed species, $69 \%$ are GuineaCongolese and $17 \%$ are Guinea-Sudano- Zambian. Species with a wide distribution represent (37\%).
Among them, Tropical Pan Africa represent 63\% and Afrotropicals 14\% (Figure-7).

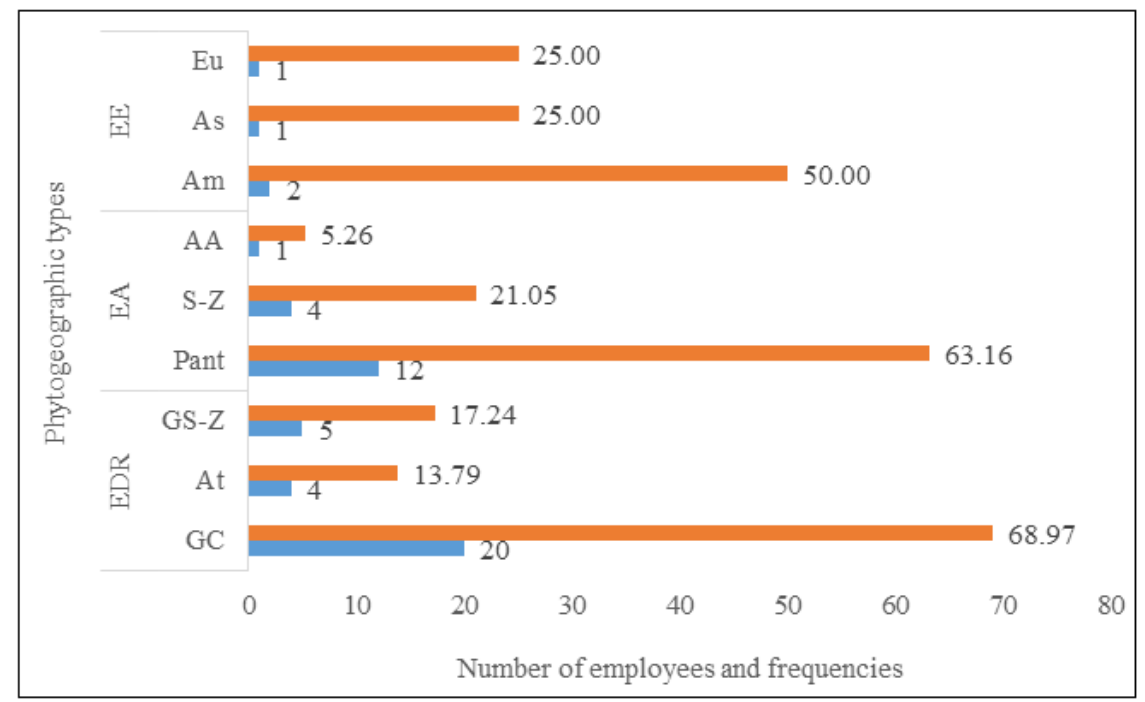

Fig-7: Weighted spectrum of phytogeographic distribution types

$\mathrm{EE}=$ Exotic $\quad$ species; $\quad \mathrm{EA}=$ African $\quad$ species; $\mathrm{EDR}=$ Regionally distributed species; GC=GuineoCongolese species; At=Afro-tropical species; GS$\mathrm{Z}=$ Guineo-Sudano-Zambian species; Pant=Pantropical species; S-Z=Sudano- Zambian species; AA=AfroAmerican species; Am=American species; As=Asian species; Eu=European species.
Of the plants identified for the treatment of sinusitis, forest species are the most solicited (32 occurrences). Of these forest species, primary forests $(56.25 \%)$ and secondary forests $(40.63 \%)$ predominate. Cultivated species $(65.00 \%)$ are the most represented among species from other biotopes (Figure-8).

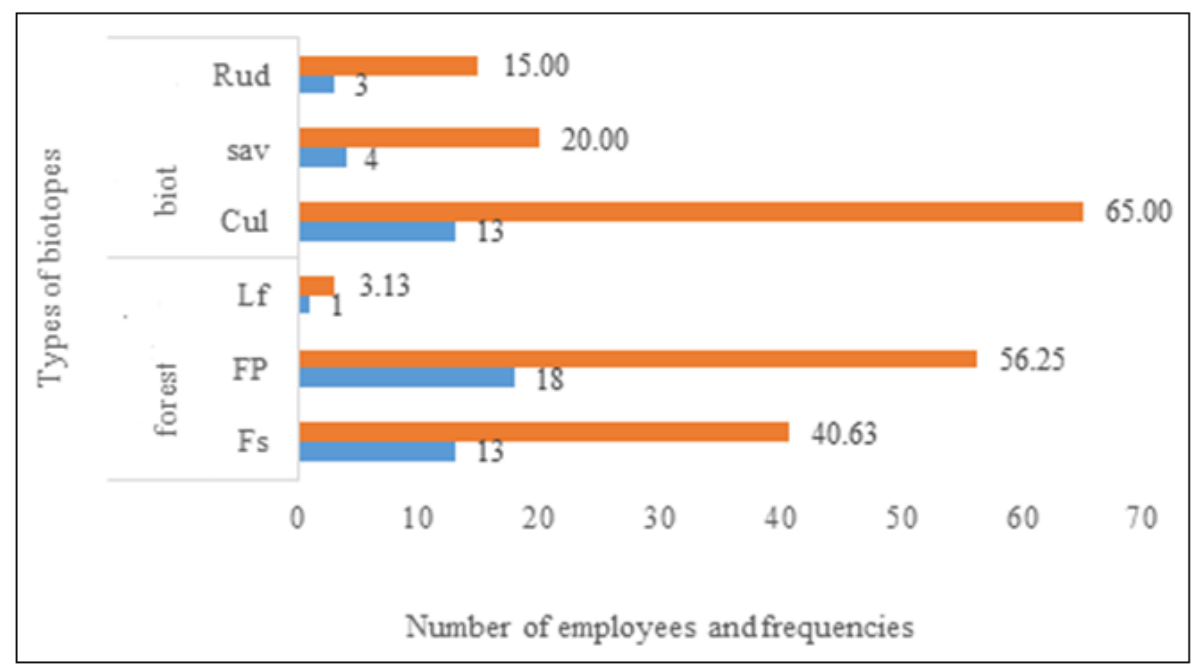

Fig-8: Weighted spectrum of biotope types

forest $=$ Forest species, Biot $=$ Spécies of others biotopes, Fs=Secondary forest $; \mathrm{Fp}=\mathrm{Primary}$ forest $; \mathrm{Lf}=\mathrm{Forestry}$ strip ; Cul=Culture ; Sav=Savannah ; Rud=Ruderal

The zoochory is the most represented mode of dissemination of diaspores and zoochorian species, the sarcochores are the most represented with 34 occurrences and a frequency of $97.14 \%$ (Figure-9). 


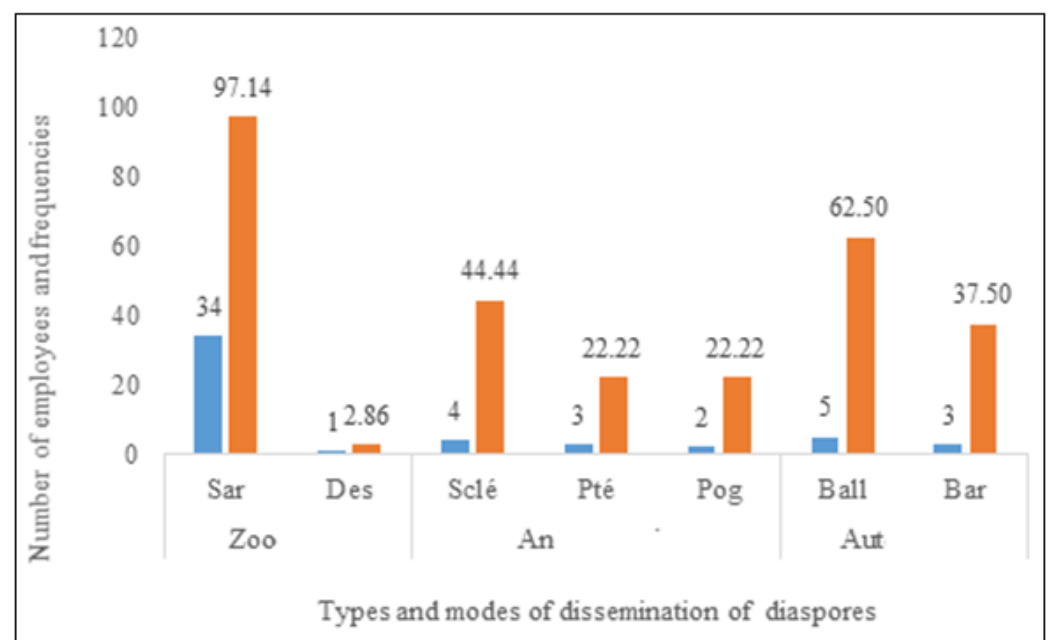

Fig-9: Weighted spectrum (\% in citations) of types and modes of diaspora dissemination

Zoo=Zoochory, An=Anemochory, Aut=Autochory, Sar=Sarcochore; Des=Desmochore; Sclerochore=Sclerochore; Pté=Ptérochore; Pog=Pogonochore; Ball=Ballochore; Bar=Barochore.

\section{Pharmacological justification for the interest in plants}

The initial validation of traditional medical practices was done by determining the chemical composition or group of some plants of interest, which would explain the effects against sinus infections. Many plants in this study have been subject to previous studies to establish their phytochemical profile. The ethnopharmacological reviews consulted reveal that these plants are rich in various phenolic compounds (tannins, phenols, flavonoids, coumarins and anthocyanins) which, in synergy with other bioactive metabolites (saponins, sterols, terpenes and anthraquinones), could solve problems related to sinusitis, in particular the infection, inflammation, pain and even nasal obstruction.

\section{DISCUSSION}

Sinusitis is described by traditional therapists as an aesthetically dirty disease, a disease of shame, with patients regularly giving off nauseating odors and constantly blowing their nose; not to mention nerve aches and violent headaches that overwhelm them. To treat this disease condition, healers from different ethnic groups rarely use isolated plants. They usually combine two to four plants in the recipes they administer to patients. This result contrasts with that of N'guessan et al., [28], who found 51 drug recipes developed to treat malaria, 44 have mono specific recipes. Similar results were found in Ivory Coast [6, 29]. These authors reported that 70 to $92 \%$ of the recipes used in ethnobotany are mono specific. According to them, this preponderance of mono specific recipes is to the advantage of patients because according to them, about $30 \%$ of fatal accidents caused by traditional medicines in Africa are due to the use of plant mixtures. This view is far from being shared by Cameroons' traditional therapists, who generally prepare medicines with at least two to three plants to treat diseases. They use mixtures to the extent that each plant has a specific role to play in treating the symptoms of a disease [15, 25]. In addition, apart from the desired therapeutic synergy effect, these traditional healers indicate that some plants can reduce the toxic effects of others when they are combined.

Many authors have identified a few plants to control respiratory diseases, in Senegal; Morocco and more recently in the Centre Region of Cameroon [1, 15, 30]. These authors already mentioned species such as Zingiber officinalis, Fagara macrophylla, Antrocaryon klaineanum, Enantia chlorantha, Spathodea campanulata, Allium sativum, Cylicodiscus gabunensis, Eucalyptus globulus and Ocimum gratissimum as plants that are used in the traditional treatment of respiratory diseases. However, very few ethnobotanical studies have cited Massullaria acuminata, Piptadeniastrum africanum, Erythrophleum suaveolens, Nicotiana tabaccum, Solanum aculiastrum and Mammea africana as plants used traditionally in therapy to treat or resolve sinusitis symptoms [15]. In contrast, Thymus vulgaris is mentioned as a plant used to control sinusitis [14, 31]. In Ivory Coast [32] recognized that Ocimum gratissimum and Kalanchoe crenata have antibacterial properties, same observation for Securidaca longepedunculata, which has been mentioned in Benin as a plant used to treat sinusitis [33].

The bark of plants is the main plant organ used in various medicinal recipes $[15,25,31]$. The interest on the bark is due to the fact that, together with the leaves, they are the organs that are easy and quick to harvest. Moreover, for the same quantity of bark, leaves and fruit, the concentration of bioactive metabolites would be higher in the bark than in the leaves or fruit [25]. In fact, according to Béné et al., [6] and Ngene et 
al., [14], these organs are the main storage site for secondary metabolites responsible for the biological properties of plants.

Fruits are seasonal organs thus not always available. The fruits of Massullaria acuminata, which are very popular for sinusitis treatment, are not only expensive (500 to $800 \mathrm{CFA}$ francs depending on size) but are also very rare in markets and not very available in villages, even during the good season. Thus, preservation methods are undertaken by healers who during the right season, dry, crush these fruits and pack them in clean and hermetically sealed bags in order to use them during shortages. These organs also face the problem of poor harvesting technique because villagers misuse species of proven interest without ever caring about their vegetative, physiological and even less about their regenerative capacity $[25,34,35]$.

Contrary to results of previous works on ethnobotany, decoction is not the best method for the preparation of recipes in the current study. It represents only $22.66 \%$ of the methods of preparation of recipes identified for sinusitis; the first being the gratering of fresh fruits and bundle the gratered fruits in leaves of Musa sp. and Xanthosoma sagittaefolium. The use of Massullaria acuminata fruits in 23 of the 78 recipes inventoried explains why this method of preparation is the most popular. However, decoction remains the fastest method of preparation of recipes; it collects the most active ingredients and reduces or eliminates the toxic effect of certain plants [36].

Sinusitis healers do not use water as a preferred solvent to prepare recipes. The juice of Citrus sp. and costus afer stems, in addition to giving the liquid pharmaceutical of the recipes, would also contain bioactive molecules capable to resolve certain symptoms related to sinusitis. Recipes for sinusitis are taken by nasal instillation of 1 to 2 drops per nostril [15]. Scientifically, the fact that the microbial strains responsible for sinusitis are located in the nasal sinuses and that this disease is described as sinus inflammation may explain the use of nasal instillation to administer recipes [3]. According to healers, this method of administration is very painful and calls for tenacity and vigilance on the part of the patient, who must strictly follow the recommendations of the traditional therapist.

The degree of similarity revealed by the dendrogram clearly shows the disparate nature of the information provided by healers in the different regions. There is every reason to believe that everyone has their own recipes for dealing with respiratory tract disorders as a whole. This situation is more visible when the information provided by all the practitioners on the same site is combined. However, the strong similarities between the information obtained in V1L (village 1 of the Littoral) and those obtained in M2L (Market 2 of the Littoral); as well as those observed between the villages and markets $\mathrm{M} 1 \mathrm{~L}, \mathrm{~V} 3 \mathrm{C}, \mathrm{M} 2 \mathrm{C}, \mathrm{V} 7 \mathrm{C}, \mathrm{V} 8 \mathrm{C}$, $\mathrm{V} 4 \mathrm{C}$ and $\mathrm{V} 2 \mathrm{~L}$ sufficiently demonstrate that there is knowledge exchange between healers from these different sites. This semblance of exchange however minimal it may be, can be explained by the fact that the NTFPs sold in the markets come from the same villages. Thus, village practitioners would sell their knowledge to market herbalists via small training courses. These exchanges are not only between specialists from the same cultural grouping; there are situations where a Béti transmits a secret to a Douala or a Bamoun and vice versa [25]. Tchatat and Ndoye [37] reported that different ethnic groups, living together or not in the same territories, use many plant species in almost the same way to treat themselves.

Fabaceae, Rutaceae and Rubiaceae are the families best represented by medicinal plant species. Topa et al., [15] while surveying the flora requested to overcome respiratory tract diseases in the Centre Region, also reported that the Fabaceae family with 10 occurrences is the best represented in the region. The results of Fatima et al. [1] on the flora requested to overcome the same diseases in Morocco reveal the opposite. These authors found that, the family Apiaceae and Lamiaceae are the two plant groups most commonly used to treat these diseases. The fact that the Cameroonian flora is different from the Moroccan flora would justify this difference; however, without forgetting that this study is mainly concerned with plants used for the treatment of sinusitis.

The proportions of the phytogeographic distribution of the species clearly reflect their endemic nature as well as the conservation of the local pharmacopoeia know-how [13]. This sufficiently shows that the popular pharmacopoeia has no influence over the traditional pharmacopoeia in the sites surveyed. The interest in woody species to treat sinusitis is detrimental because, as Dibong et al., [25] reported, there are very vulnerable species that regenerate very slowly and, when poorly exploited, easily degenerate. The abundance of cultivated species in the different Regions provides sufficient evidence that spontaneity in regeneration and domestication of species are a guarantee of sustainable resource use [31]. The importance of zoochore species reflects both the forest origin of the plants listed in the sinusitis recipes and the important role of wildlife in forest regeneration [10, $13]$

Massullaria acuminata fruit juice is used in traditional medicine in Sierra Leone as an eye drop against eye germs. In Nigeria, barks of plant roots are used as a traditional dental hygiene brush [38]. Decoction or infusion of plant barks is recognized as a powerful aphrodisiac and an anti-carcinogen [39]. Anthocyanins, catechic tannins, quinones and various 
other compounds contained in the fruits of this plant gives it a strong antioxidant, anti- inflammatory and antimicrobial property, particularly against clinical strains of Plasmodium falciparum [38-40]. Village healers also recommend its use in nasal instillation to relieve nerve pain. The dried fruit powder of Massullaria acuminata is very toxic, even via nasal instillation. According to traditional therapists, the decoction of fresh fruit, taken as a drink, causes nausea and throat irritation.

The bark of Piptadeniastrum africanum associated with Baillonella toxisperma is commonly used in Cameroonian traditional medicine to treat hemorrhoids. Traditional healers in this country mention that this plant is an antibiotic and antiinflammatory used in many recipes to relief urogenital infections, gastric pain, dysmenorrhea, back pain and male impotence [25]. Bark decoctions are administered internally to treat coughs, bronchitis, headaches and mental disorders. Piptadeniastrum africanum bark is rich in tannins, anthraquinones, saponins, alkaloids and glycosides [41]. Saponins and tannins have been reported to confer antioxidant, analgesic, microbial, ulcer, anticancer and hepato-protective properties to plants [31, 42]. These different properties could justify the involvement of Piptadeniastrum africanum in the treatment of sinus symptomatologies.

According to traditional market specialists in Yaoundé and Douala, the bark of Mammea africana is used to prepare most of the recipes to treat venereal diseases. The bark of Mammea africana is rich in flavonoids, terpenes, anthraquinones, tannins and saponins [43]. These same authors have shown that Mammea africana bark has pronounced effects against strains of Plasmoduim falciparum in the same way as chloroquine and therefore can be used in the treatment of malaria. In addition, Ouahoua et al., [44] reported that coumarins present in the bark decoction of this tree inhibited the growth of Staphylococcus aureus. This pronounced interest against these microbial strains would allow Mammea africana to be designated as a plant of interest to solve problems related to sinusitis.

\section{However, Cylicodiscus gabunensis remains a} potent antimicrobial [45]. The traditional pharmacopoeia in Cameroon uses this species for external use to treat chickenpox, measles, fungal infections and diaper rashes. Its decoction taken orally cleanses the body against many germs. For example, it is used in recipes to treat typhoid, amoebic dysentery, chlamydia and many other venereal diseases [14, 25, 46]. Chemical screening of the bark decocted from Cylicodiscus gabunensis revealed the presence of alkaloids, flavonoids, tannins, sterols and saponins in large quantities, which gave it a high antibacterial potential, particularly against Salmonella typhi and Staphylococcus aureus strains [47]. Thus, the sensitivity of Staphylococcus aureus, one of the bacteria responsible for sinusitis, to the decoction of Cylicodiscus gabunensis bark could explain the use of this plant in the treatment of sinusitis.

The bark of Erythrophleum suaveolens is rich in various phenolic compounds, alkaloids, sterols and saponins and that all these compounds, more specifically cassaidin, cassaine and cassamine, were responsible for their analgesic, anti-inflammatory and fungal properties $[48,49,50]$. However, the bark of this plant is banned as a drink by all the traditional therapists of the sites surveyed in the current study because they claim, the decoction of these barks is of proven toxicity. Thus, its use to treat sinusitis is only by nasal instillation.

Alium sativum is recognized in popular medicine as a treatment for many respiratory tract disorders including coughs, colds, flu and asthma [1]. Garlic has well-known antibacterial and antifungal properties. It is used to solve problems of gastroenteritis, pneumonia, typhoid and gingivitis [14, $31,51]$. In addition, interviews with respondents reveal that daily consumption of garlic is excellent for health because it has a protective, anti-viral, anti-bacterial, anti-parasitic and even relieves pain and inflammation. The sulfides present in Alium sativum are believed to be responsible for the many benefits recognized $[15,52]$.

Chemical screening of the aqueous bark extract of Spathodea campanulata reveals a richness of this plant in phenolic compounds such as polyphenols, flavonoids, tannins, coumarins and many phenolic acids such as spathodic acid, ursolic acid, cafeic acid and tomentosolic acid $[53,54]$. These authors also mention the presence in bark extracts of the trunk of Spathodea campanulata, sterols and saponins. This plant has an anti-microbial power conferred by all these phenolic compounds [54]. For example, it is used to treat microbial diseases of the digestive tract, such as dysentery, typhoid and gastric ulcers $[54,55]$. It is also used to treat herpes and many other viral diseases. In addition, bark extracts from this tree have shown antioxidant, anti-inflammatory and diuretic activity [53, 55]. All these properties could justify the use of Spathodea campanulata in the traditional treatment of sinusitis.

Lemon is a popular pharmacopoeia plant widely used for its bactericidal, antiseptic, refreshing, febrifuge, diuretic, anti-rheumatic, anti-taste, antiarthritic, anti-sclerotic, antiscorbutic, blood thinning, hypotensive, depurative properties [14, 56]. It is used in anthroposophic medicine to treat seasonal allergic rhinitis, known as "hay fever". Its richness in vitamin $\mathrm{C}$ and flavonoids are the basis of its therapeutic properties [57]. Its use against infectious diseases, lung infections and pulmonary infections and tuberculosis 
has been identified in the work of [56]. Citrus limon has often been the most requested associate plant in the preparation of drug recipes [13]. According to healers, it would preserve drug recipes as long as possible, it would tonify the patient weakened by the disease and it would reinforce the therapeutic effect of other plants $[25,58]$.

\section{CONCLUSION}

Herbal therapy is a valuable asset in solving sinus problems related diseases. The exploitation of medicinal plants is not only an interesting issue in terms of public health, but also an economic issue for those holding the traditional know-how. Additionally, the exploitation of traditional therapy is of a great ecological interest as it values endemic plants and biodiversity. Plants used in the treatment recipes of sinusitis are unanimously approved by traditional healers, whatever be the region they come from in Cameroon. These endemic plants, available in the forest zone, and are rich in bio-active metabolites, each of them having a different effect on sinus symptoms. Thus, traditional therapists, in their recipes, associate them in an empirical way with goal of obtaining an immediate and more pronounced curative effect. It would therefore be wise to scientifically exploit these empirical practices to produce a drug that can cure sinusitis, which is a disease to which populations are exposed to.

\section{REFERENCES}

1. Fatima, E., Ben Akka, F., Dahmani, J., Belahbib, N., \& Zidane, L. (2013). Ethnobotanical study of medicinal plants used in the treatment of the respiratory tract infections in the central Moroccan plateau. Journal of Animal \& Plant Sciences, 25:3886-3897.

2. Porto, V., Fol, J., \& Tavaglione, F. (2012). Community immersion in Yaoundé, Cameroon. 62.

3. Champsaur, P., Pascal, T., Vidal, V., Gaubert, J. V., Bartoli, J. M., \& Moulin, G. (2003). Radioanatomy of the sinuses of the face. Journal Radiol, 84:885-900.

4. [4] Desrosiers, M., Gerald, A. E., Paul, K. K., Erin, D. W., Kaplan, A., Bouchard, J., Ciavarella, A. B. A., Doyle, P. W., Amin, R. J., Eric, S. L., Atreyi Mukherji, Schellenberg, R. R., Peter, S., \& Ian, J. W. (2011). Canadian guidelines for the management of acute rhino sinusitis.

5. Pleis, J., \& Lucas, J. (2009). Summary health statistics for U.S. adults: National 4. Health Interview Survey, 2007. National Center for Health Statistics. Vital Health Stat, 10.

6. Béné, K., Camara, D., Fofie N'Guessan, B. Y., Kanga, Y., Yapi, A. B., Yapo, Y. C., Ambe, S. A., \& Zirihi, G. N. (2016). Ethnobotanical study of medicinal plants used in the Transua Department, Zanzan District (Côte d'Ivoire). Journal of Ear,
Nose, Throat, Cervical and Facial Surgery, 40:143-193.

7. Dozon, J. P. (1987). "What it means to value traditional medicine", African Politics. Health policies, 28:9-20.

8. Biyiti, L. F., Meko'o, D. J. L., Tamzc, V., \& Amvam Zollo, P. H. (2004). Research of the antibacterial activity of four Cameroonian medicinal plants. Pharm Med Trad Afr, 13:11-20.

9. Koné, D. (2009). Ethnobotanical investigation of six Malian medicinal plants - extraction, identification of alkaloids - characterization, quantification of polyphenols: study of their antioxidant activity. $\mathrm{PhD}$ thesis University of Bamako, Mali. 157.

10. Betti, J. L. (2002). Medicinal plants sold in Yaoundé markets, Cameroon. African study Monographs, 23, 47-64.

11. Dibong, S. D., Mpondo Mpondo, E., Ngoye, A., Kwin, N. F., \& Betti, J. L. (2011). Ethnobotany and phytomedicine of medicinal plants sold in the markets of Douala, Cameroon. Journal of Applied Biosciences, 37:2496-2507.

12. Mpondo Mpondo, E., Dibong, S. D., Ladoh, Y. C. F., Priso, R. J., \& Ngoye, A. (2012). Phenol plants used by the populations of Douala city. Journal of Animal and Plant Sciences, 15:2083-2098.

13. Kidik Pouka, M. C., Ngene, J. P., Ngoule, C. C., Mvogo Ottou, P. B., Ndjib, R. C., Dibong, S. D., \& Mpondo Mpondo, E. (2015). Characterization of flavonoid medicinal plants in the markets of Douala (Cameroon). International Journal Biological Chem Science, 9:1494-1516.

14. Ngene, J. P., Ngoule, C. C., Kidik Pouka, C. M., Mvogo Ottou, P. B., Ndjib, R. C., Dibong, S. D., \& Mpondo Mpondo, E. (2015). Importance in the traditional pharmacopoeia of flavonoid plants sold in the markets of Douala Est (Cameroon). Journal of Applied Biosciences, 88:8194-8210.

15. Mpondo Mpondo, E., Vandi, D., Ngouondjou Foze, T., Mvogo Ottou, P. B., Embolo, E. E., \& Dibong, S. D. (2017). Contribution of the populations of the villages of central Cameroon to the traditional treatment of the respiratory tract diseases. Journal of Animal \&Plant Sciences, 32:5223-5242.

16. Topa, G., Karsenty, A., Megevand, C., \& Debroux, L. (2010). Cameroon's tropical rainforests: A decade of reforms. 2010 The International Bank for Reconstruction and Development/The World Bank 1818 H Street, NW, Washington, DC 20433. 197.

17. Fonkoué, J. (1981). Trials of nomenclature of the populations and languages of Cameroon, African Center of Study, Center for Analyses and Documentary Research for Black Africa, Paris, 2.

18. Yakan, M. Z. (1999). «African peoples and nations by country: Cameroon », in Almanac of African Peoples \& Nations, Transaction Publishers, New Brunswick, N.J., 37-39. 
19. Schnell, R. (1960). Grazing and plant conservation techniques in tropical countries. Journal Agricultural Too much Bot Appl, 7:1-48.

20. Mullenders, W. (1954). The phytogeographical position of the Belgian highlands. Vegetation, 56:112-119.

21. Aubréville, A. (1962). Chorological position of Gabon. Flora of Gabon, 2:3-11.

22. Evrard, C. (1968). Ecological research on the forest stand of hydromorphic soils in the central Congolese basin. INEAC Publ. Sér. Sc. N 110 Brussels, 295.

23. Letouzey, R. (1985). Phytogeographic map of Cameroon at 1/500000 n04. IRAICIV, University of Toulouse, France, 240.

24. White, F. (1986). The vegetation of Africa. Memorandum accompanying the vegetation map of Africa, UNESCO/Aetfat/Unso. 384.

25. Dibong, S. D., Mvogo Ottou, P. B., Vandi, D., Ndjib, R. C., Monkam Tchamaha, F., \& Mpondo Mpondo, E. (2015). Ethnobotany of medicinal plants against hemorrhoids from markets and villages in Central and Coastal Cameroon. Journal Applied Biosci, 96:9072-9093.

26. Andrade-Cetto, A., \& Heinrich, M. (2011). From the field into the lab: useful approaches to selecting species based on local knowledge. Front. Pharmacology, 2:20.

27. Betti, J. L., Yongo, O. D., Obiang Mbomio, D., Iponga, D. M., \& Ngoye, A. 2013. An Ethnobotanical and Floristical Study of Medicinal Plants Among the Baka Pygmies in the Periphery of the Ipassa- Biosphere Reserve, Gabon. European Journal of Medicinal Plants, 3:174

28. N'Guessan, K., Tra Bi, F. H., \& Koné, M. W. (2009). Ethnopharmacological study of antimalarial plants used in traditional medicine in the Abbey and Krobou of Agboville (Côte d'Ivoire). Ethnopharmacologia, 44:42-50.

29. Monnet, T. M. S. (2013). Ethnobotanical study of anti-diabetic medicinal plants sold in the markets of the municipality of Abobo in the District of Abidjan (Côte d'Ivoire). Master II thesis in botany, UFR Biosciences, Félix Houphouët-Boigny University, 50.

30. Diaoune. (2006). Plants and medicines used against cough: survey of markets and wholesalers in the Dakar region (Senegal). Doctoral Thesis, Cheikh Anta Diop University, Senegal, 85.

31. Vandi, D. Nnanga Nga, E. Betti, J. L., Etame Loe, G. M., Mvogo Ottou, P. B., Priso, R. J., Ngouondjou Foze, T., Ngo Boumsong, P. C., Dibong, S. D., \& Mpondo Mpondo, E. (2016). Contribution of the populations of the cities of Yaoundé and Douala to the knowledge of tannin and anthocyanin plants. Journal of Animal \& Plant Sciences, 30:4797-4814.

32. Fézan, H., Tra Bi, G. M., Irié, Kohué, C. C., \& N'gaman Clejesson, H. B. M. (2008). Studies of some therapeutic plants used in the treatment of high blood pressure and diabetes: two emerging diseases in Côte d'Ivoire. Science \& Nature, 5:3948.

33. Adomou, A. C., Yedomonhan, H., Djossa, B., Legba, S. I., Oumorou, M., \& Akoegninou, A. (2012). Ethnobotanical study of medicinal plants sold in the Abomey-Calavi market in Benin. International Journal Biological Chemistry Science, 6:745-772.

34. Nacoulma-Ouédraogo, O. (1996). Medicinal plants and traditional medical practices in Burkina Faso: the case of the Central Plateau, $\mathrm{PhD}$ thesis in Natural Sciences, University of Ouagadougou, (Burkina-Faso), 605.

35. Priso, R. J., Nnanga, J. F., Etame, J., Din, N., \& Amougou, A. (2011). Non-timber forest products of plant origin: important value in some markets in the Littoral-Cameroon region. Journal Applied Biosciences, 40:2715-2726.

36. Salhi, S., Fadli, M., Zidane, L., \& Douira, A. (2010). Floral and ethnobotanical studies of medicinal plants in the city of Kenitra (Morocco). Lazaroa, 31:133-146.

37. Tchatat, M., \& Ndoye, O. (2006). Study of nontimber forest products in Central Africa: realities and perspectives. Tropical Woods and Forests, 288:27-39.

38. Aderinokun, G. A., Lawoyin, J. O., \& Onyeaso, C. O. (1999). "Effect of two common Nigerian chewing sticks on gingival health and oral hygiene." Tropical odonto-stomatology, 22:13-18.

39. Yakubu, M. T., \& Akanji, M. A. (2010). Effect of Aqueous Extract of Massularia acuminate Stem on Sexual Behaviour of Male Wistar Rats. EvidenceBased Complementary and Alternative Medicine, 10.

40. Maloueki, U., Kunyima, K. P., Mbomba, I. D., Dani, N. A., Lukuka, K. A., Lami, N. J., Mpiana, P. T., Ngbolua, K.N., Ndimbo, K. S. P., Mbomba, N. B., \& Musuyu Muganza, C. D. (2015). Antioxidant and antiplasmodial activities of extracts of Massularia acuminata (Rubiaceae). Phytotherapy 13:389-395.

41. Owoeye, E. A., Ogboru, R. O., Bakpolor, V. R., \& Omobude, D. E. (2018). Phytochemical screening and proximate analysis of the bark of Piptadeniastrum africanum Hok (Fabaceae). World News of Natural Sciences, 19:135-141.

42. Tadros, M. M., Ghaly, N. S., \& Moharib, M. N. (2008). Molluscicidal and Schistosomicidal activities of a steroidal saponin containing fraction from Dracaena fragrans Linn. Journal Egypt Soc Parasitol, 38, 585-985.

43. Jude, E., Okokon, Aniekan, E., Udokpoh \& Essiet, G. A. (2006). Antimalarial activity of Mammea africana. Afr. J. Trad. Compl. And Altern. Med., 3:43-49. 
44. Ouahoua, B. M. W., Azebaze, A. G. B., Meyer, M., Bodo, B., Fomum, Z. T., \& Nkengfack, A. E. (2004). Cytotoxic and antimicrobial coumarins from Mammea africana. Annals of Tropical Medicine and Parasitology, 98:733-739.

45. Mabeku Kouitcheu, L. B., Penlap beng, V., Kouam, J., Ngadjui, B. T., Fomum, Z. T., \& Etoa, F. X. (2006). Evaluation of antidiarrhoeal activity of the stem bark of Cylicodiscus gabunensis (Mimosaceae). African Journal of Biotechnology, 5:1062-1066.

46. Ladoh-Yemeda, C. F., Vandi, D., Dibong, S. D., Mpondo Mpondo, E., Wansi, J. D., Betti, J. L., Choula, F., Din N., \& Tomedi, E. M. (2016). Ethnobotanical study of medicinal plants sold in the markets of the city of Douala, Cameroon. Journal of Applied Biosciences, 99, 9450-9468.

47. Ayuk, E. L., Njokunwogbu, A. N., Ilo, S. U., Engwa, G. A., \& Oni, T. O. (2015). Screening of phytochemicals and biological potential of aqueous, methanol and hexane extracts of Cylicodicus gabunensis stem bark. American Journal of Biochemistry, 5:30-34.

48. Unuorah, E. O. (2000). The wood preservative potentials of heartwood extracts of Milicia excels and Erythrophleum suaveolens. Bio Technol, 75:171-173.

49. Yemoa, A. L., Gbenou, J. D., Johnson, R. C., Djego, J. G., Zinsou, C., Moudachirou, M., QuetinLeclercq, J., Bigot, A., \& Portaels, F. (2008). Identification and phytochemical study of plants used in the traditional treatment of Buruli ulcer in Benin. Ethnopharmacologia, 42:48-55.

50. Mowobi, G. G., Osuji, E. C., Abubakar, S., \& Joseph, U. E. (2016). Phytochemical screening, pharmacognostic analysis and thin layer chromatographic studies of red water tree
(Erythrophleum suaveolens Guill and Per Brenan) stem bark. Journal of Emvironment and Life Sciences, 1:32-38.

51. Yinyang, J., Mpondo Mpondo, E., Mchatat, M., Ndjib, R. C., Mvogo Ottou, P. B., \& Dibong, S. D. (2014). Alkaloid plants used by the populations of Douala city (Cameroon). Journal of Applied Biosciences, 78:6600-6619.

52. Josling, P. (2001). Preventing the common cold with a garlic supplement: a double-blind, placebo controlled survey. Adv Ther, 18:189-93.

53. Nazif, N. M. (2007). Phytochemical and antioxidant activity of Spathodea campanulata P. Beauvois growing in Egypt. Natural Product Sciences, 13:11-16.

54. Pianaro, A., Pinto, J. P., Ferreira, D. T., Ishikawa, N. K., \& Braz-Filho, R. 2007. Iridoid glucoside and antifungal phenolic compounds from Spathodea campanulata roots. Ciências Agrárias, Londrina, 28, 251-256.

55. Prosper-Cabral, N., Biapa, Agbor, GA, Oben, J. E., \& Ngogang, J. Y. (2007). Phytochemical studies and antioxidant properties of four medicinal plants used in Cameroon. African Journal Trad Cam, 4:495- 500.

56. Hseini, S., \& Kahouadji, A. (2007). Ethnobotanical study of the medicinal flora in the Rabat region (Western Morocco). Lazaroa, 28:79-92.

57. Park, S. H., Park, E. K., \& Kim, D. H. (2005). Passive cutaneous anaphylaxis-inhibitory activity of flavanones form Citrus unshiu and Poncirus trifoliata. Planta Med., 71:24-27.

58. Dibong, S. D., Mpondo Mpondo, E., Ngoye, A., \& Kwin, N. F. (2011). Medicinal plants used by the Bassa populations of the Douala region of Cameroon. International Journal of Biological and Chemical Sciences, 5:1105-1117. 